\title{
IMPLEMENTASI METODE PEMBELAJARAN COURSE REVIEW HORAY UNTUK MENINGKATKAN AKTIVITAS DAN HASIL BELAJAR JURNAL PENYESUAIAN
}

\author{
Rukmanda Dias Aksiwi \\ Prodi Pendidikan Akuntansi Universitas Negeri Yogyakarta \\ rukmandadias@gmail.com \\ Endra Murti Sagoro \\ Jurusan Pendidikan Akuntansi Universitas Negeri Yogyakarta
}

\begin{abstract}
Abstrak
Penelitian ini adalah Penelitian Tindakan Kelas yang bertujuan untuk meningkatkan aktivitas dan hasil belajar jurnal penyesuaian pada siswa kelas X Akuntansi SMK Muhammadiyah 2 Moyudan Tahun Ajaran 2013/2014 dengan implementasi Metode Pembelajaran Course Review Horay. Penelitian ini dilaksanakan dalam bentuk kolaboratif yang dilaksanakan dalam dua siklus. Teknik pengumpulan data menggunakan observasi, tes, catatan lapangan dan dokumentasi. Analisis data yang digunakan adalah deskriptif kuantitatif dengan persentase. Hasil penelitian menunjukkan Implementasi Metode Pembelajaran Course Review Horay dapat meningkatkan aktivitas dan hasil belajar jurnal penyesuaian yang dibuktikan dengan peningkatan skor aktivitas belajar dari siklus I dan siklus II secara berturut-turut yaitu kegiatan-kegiatan visual 36,84\%, 85,71\%, kegiatan-kegiatan lisan $34,21 \%, 74,60 \%$, kegiatan-kegiatan mendengarkan 57,89\%, 85,71\%, kegiatan-kegiatan menulis 39,47\%, 60,71\%, kegiatan-kegiatan mental 44,74\%, 75,00\%, kegiatan-kegiatan metrik 72,37\%, 98,81\%, dan kegiatan-kegiatan emosional 40,79\%, 78,57\%. Peningkatan hasil belajar dilihat dari ketercapaian Kriteria Ketuntasan Minimal (KKM) dari siklus I dan siklus II yaitu sebesar 10,53\% menjadi 76,19\% dari jumlah siswa.
\end{abstract}

Kata kunci: Penelitian Tindakan Kelas, Course Review Horay, Aktivitas dan Hasil Belajar

\begin{abstract}
This research was Classroom Action Research which aimed to improve activities and achievement of Adjustment Journal of Students in X Accounting of Moyudan Muhammadiyah Vocational High School 2 in 2013/2014 by implementation of Course Review Horay Learning Method. This research was conducted by collaboration in two cycles. Observation, test, anecdote, and document study are used for data collecting. Quantitative description and percentage were used for data analyzing. The result showed that implementation of Course Review Horay Learning Method improved activities and achievement of adjustment journal from Cycle I to Cycle II in series score as high as of visual activities from $36.84 \%$ to $85.71 \%$, oral activities from $34.21 \%$ to $74.60 \%$, aural activities from $57.89 \%$ to $85.71 \%$, writing activities from $39.47 \%$ to $60.71 \%$, mental activities from $44.74 \%$ to $75.00 \%$, matrix activities from $72.37 \%$ to $98.81 \%$, and emotional activities from $40.79 \%$ to $78.57 \%$. The improvement of achievement was shown by percentage achievement of Minimum Passing Grade from Cycle I to Cycle II as high as from $10.53 \%$ to $76.19 \%$ of all students.
\end{abstract}


Keywords: Classroom Action Research, Course Review Horay, Activities and Achievement of Adjusting Journal

\section{PENDAHULUAN}

Negara Indonesia merumuskan sebuah tujuan mulia pendidikan yang tercantum dalam pembukaan UndangUndang Dasar 1945 alinea IV yaitu mencerdaskan kehidupan bangsa. "Wujud tujuan pendidikan dapat berupa pengetahuan, keterampilan, nilai, dan sikap (Arif Rohman, 2009: 87). Benyamin Bloom (1956) dalam Nana Sudjana (2005: 22) menyebutkan tujuan pendidikan secara menyeluruh mencakup ranah kognitif, afektif, dan psikomotorik. Menurut Nana Sudjana (2005: 22-23) ranah kognitif berkenaan dengan hasil belajar intelektual, ranah afektif berkenaan dengan sikap, dan ranah psikomotorik berkenaan dengan hasil belajar keterampilan dan kemampuan bertindak. Menurut Nana Sudjana (2005: 1) penilaian program pendidikan dapat dilihat dari aspek proses dan hasil. Proses pembelajaran dikatakan baik apabila siswa menunjukkan aktivitas belajar yang tinggi selama kegiatan belajar mengajar, sedangkan aspek hasil dapat dilihat dari perolehan nilai yang tinggi, yang ditunjukkan dengan tercapainya Kriteria Ketuntasan Minimal (KKM). "Semakin baik proses pembelajaran dan keaktifan siswa dalam mengikuti proses pembelajaran, maka seharusnya hasil belajar yang diperoleh siswa akan semakin tinggi sesuai dengan tujuan yang telah dirumuskan sebelumnya" (Asep Jihad dan Abdul Haris, 2008: 20).

Pembelajaran yang ideal adalah pembelajaran yang berpusat pada aktivitas belajar siswa. Adanya aktivitas belajar siswa yang tinggi diharapkan dapat meningkatkan hasil belajar siswa.Namun pada kenyataannya banyak sekolah yang belum dapat memenuhi kriteria pembelajaran ideal tersebut, salah satunya SMK Muhammadiyah 2 Moyudan. Berdasarkan observasi awal penulis pada tanggal 13 September 2013 di kelas X Akuntansi SMK Muhammadiyah 2 Moyudan, pelaksanaan pembelajaran belum berlangsung secara optimal sehingga menyebabkan hasil belajar siswa kurang maksimal. Masalah yang ditemui adalah aktivitas belajar siswa dalam mengikuti pembelajaran masih rendah sehingga hasil belajar siswa kurang maksimal. Hal ini terlihat dari $70 \%$ atau 14 dari 20 siswa hanya duduk diam mendengarkan informasi, mencatat, kemudian mengerjakan latihan soal sebagai akibat dari pembelajaran yang bersifat teacher centered. Peran siswa 
dalam kegiatan pembelajaran masih kurang aktif, telihat sebanyak 11 dari 20 siswa atau sebesar $55 \%$ siswa cenderung kurang memperhatikan, terutama siswa yang duduk di bagian belakang. Berbagai kegiatan yang dilakukan diantaranya melamun, berbincang, atau menulis hal-hal yang tidak terkait dengan materi pelajaran. Siswa yang bertanya pada guru hanya sebanyak 5 dari 20 siswa atau sebesar 25\%. Pada saat guru memberikan kesempatan untuk bertanya, justru tidak ada siswa yang mengajukan pertanyaan. Pada saat pembagian tugas, hanya sebesar $30 \%$ atau 6 dari 20 siswa yang berani menuliskan jawaban di papan tulis. Pada saat pembagian tugas secara berkelompok, mereka cenderung mengandalkan satu orang dan tidak ada tanggungjawab yang pasti dari setiap anggota kelompok sehingga sulit untuk mengukur hasil belajar siswa. Guru hanya menggunakan metode ceramah dan latihan soal sehingga suasana pembelajaran menjadi tegang dan kurang menarik mengakibatkan kondisi kelas menjadi tidak kondusif.

Penerapan metode pembelajaran yang tidak tepat di dalam kelas dapat mengakibatkan proses pembelajaran tidak maksimal. Guru perlu menerapkan metode pembelajaran yang tepat sebagai strategi untuk meningkatkan aktivitas belajar di kalangan siswa sehingga pencapaian hasil pembelajaran lebih maksimal. Penerapan metode pembelajaran yang tidak tepat di dalam kelas dapat mengakibatkan proses pembelajaran tidak maksimal. Metode pembelajaran yang berorientasi pada peningkatan aktivitas dan hasil belajar siswa saat ini telah banyak berkembang, salah satunya adalah metode pembelajaran kooperatif, diantaranya Course Review Horay. Metode Pembelajaran Course Review Horay belum pernah diterapkan dalam kegiatan pembelajaran pada kelas $\mathrm{X}$ Akuntansi SMK Muhammadiyah 2 Moyudan Tahun Ajaran 2013/2014. Penerapan pembelajaran ini bertujuan agar siswa kelas $\mathrm{X}$ Akuntansi SMK Muhammadiyah 2 Moyudan mempunyai jiwa kemandirian dalam belajar, menumbuhkan daya kreativitas, serta diharapkan lebih aktif dalam mengungkapkan pendapat dan bekerjasama, tidak hanya mendengar, membaca, dan menulis apa yang disampaikan guru dalam pembelajaran.

Metode ini merupakan metode pembelajaran dengan pengujian pemahaman siswa menggunakan kotak yang berisi nomor untuk menuliskan jawabannya. Siswa yang lebih dulu mendapatkan tanda atau jawaban benar langsung berteriak "horay" atau yel-yel yang telah dipersiapkan sebelumnya. 
Menurut Sulis Setiana (2012) Course Review Horay adalah model pembelajaran yang dapat menciptakan suasana kelas menjadi meriah dan menyenangkan. Eko Sugandi dan Sri Rahayu (2012) menyatakan bahwa Course Review Horay tidak hanya menginginkan siswa untuk belajar keterampilan dan isi akademik, tetapi juga melatih siswa untuk mencapai tujuan-tujuan hubungan sosial yang pada akhirnya mempengaruhi prestasi akademik siswa.

Menurut Dessy Anggraeni (2011), pembelajaran Course Review Horay adalah salah satu pembelajaran yang dapatmendorong siswa untuk ikut aktif dalam belajar. Pembelajaran Course ReviewHoray dicirikan oleh struktur tugas, tujuan, dan penghargaan kooperatif yang melahirkansikap ketergantungan positif di antara sesama siswa, penerimaan terhadap perbedaanindividu dan mengembangkan keterampilan bekerjasama. Kondisi sepertiini akan memberikan kontribusi yang cukup berarti untuk membantu siswa yang kesulitandalam mempelajari konsepkonsep belajar, pada akhirnya setiap siswa dalam kelas dapat mencapai hasil belajar yang maksimal.

Berdasarkan wawancara penulis dengan guru mata pelajaran Produktif Akuntansi SMK Muhammadiyah 2 Moyudan mengenai materi pembelajaran yang diajarkan di kelas $\mathrm{X}$, pokok bahasan Jurnal Penyesuaian merupakan materi yang dianggap paling sulit untuk dipahami oleh siswa.

Berdasarkan uraian tersebut, rumusan masalah dari penelitian ini adalah:

1. "Apakah Implementasi Metode Pembelajaran Course Review Horay dapatmeningkatkan aktivitas belajar jurnal penyesuaian siswa kelas $\mathrm{X}$ Akuntansi SMK Muhammadiyah 2 Moyudan Tahun Ajaran 2013/2014?”

2. “Apakah Implementasi Metode Pembelajaran Course Review Horay dapatmeningkatkan hasil belajar jurnal penyesuaian siswa kelas X Akuntansi SMK Muhammadiyah 2 Moyudan Tahun Ajaran 2013/2014?”

\section{METODE}

\section{Desain Penelitian}

Jenis penelitian ini adalah Penelitian Tindakan Kelas (Classroom Action Research) dengan bentuk kolaborasi antara penulis dengan guru mata pelajaran Akuntansi. Prosedur yang digunakan adalah proses penelitian tindakan model Kemmis dan Taggart, dengan melakukan 2 siklus.

\section{Subyek dan Objek Penelitian}


Subyek penelitian ini adalah seluruh siswa kelas X Akuntansi SMK Muhammadiyah 2 Moyudan Tahun Ajaran 2013/2014 yang berjumlah 21 siswa, sedangkan objek penelitian ini adalah Aktivitas dan Hasil Belajar Jurnal Penyesuaian pada Siswa Kelas $X$ Akuntansi yang hendak ditingkatkan melalui Implementasi Metode Pembelajaran Course Review Horay.

\section{Prosedur Penelitian}

Penelitian ini dilaksanakan dalam dua siklus yang meliputi perencanaan, pelaksanaan, pengamatan, dan refleksi pada setiap siklusnya. Adapun prosedur pelaksanaannya adalah sebagai berikut:

1. Siklus I

a. Perencanaan tindakan

Perencanaan tindakan diawali dengan membuat Rencana Pelaksanaan Pembelajaran (RPP) untuk pokok bahasan materi Jurnal Penyesuaian menggunakan kombinasi Metode Pembelajaran Course Review Horay dengan metode pembelajaran lain seperti ceramah dan latihan soal. Selanjutnya, membuat lembar observasi, pedoman observasi, dan format catatan lapangan, menyiapkan soal dan mendokumentasikan setiap kegiatan. b. Pelaksanaan Tindakan

Apabila tahap perencanaan tindakan telah matang, maka langkah selanjutnya yaitu melaksanakan rencana tersebut di kelas dengan berpedoman pada Rencana Pelaksanaan Pembelajaran yang telah disusun sebelumnya. Pada tahap ini guru sebagai tenaga pengajar melaksanakan tindakan berdasarkan RPP yang telah disusun, sedangkan penulis melakukan penelitian terhadap segala kegiatan yang dilakukan siswa selama proses pembelajaran dengan menggunakan Metode Pembelajaran Course Review Horay. Pelaksanaan ini bersifat fleksibel atau berubah-ubah sesuai dengan situasi dan kondisi yang terjadi di lapangan.

c. Pengamatan

Kegiatan observasi dilakukan bersamaan dengan pelaksanaan tindakan. Penulis melakukan pengamatan terhadap kegiatan pembelajaran dengan menerapkan Metode Pembelajaran Course Review Horay menggunakan lembar observasi dan mencatat proses pembelajaran yang berlangsung dalam catatan lapangan. Dalam melakukan pengamatan penulis dibantu oleh tiga observer. Pada 
tahap ini penulis juga membagikan tes untuk mengukur hasil belajar siswa.

d. Refleksi (Reflecting)

Proses refleksi dilakukan dengan diskusi bersama guru mata pelajaran mengenai catatan lapangan dan lembar observasi yang dibuat selama proses pembelajaran. Dari catatan lapangan dan lembar observasi tersebut, dilakukan evaluasi terhadap pelaksanaan pembelajaran, kemudian dilakukan identifikasi permasalahan yang muncul selama proses pembelajaran. Selanjutnya, disusun pemecahan atas masalah-masalah yang muncul agar dapat dibuat rencana perbaikan pada siklus II.

2. Siklus II

a. Perencanaan Tindakan

Perencanaan tindakan siklus II diawali dengan membuat Rencana Pelaksanaan Pembelajaran (RPP) untuk pokok bahasan materi Jurnal Penyesuaian menggunakan kombinasi Metode Pembelajaran Course Review Horay dengan metode pembelajaran lain yaitu ceramah dan latihan soal. RPP yang disusun didasarkan pada hasil refleksi siklus I. b. Pelaksanaan Tindakan

Pelaksanaan tindakan pada siklus II pada dasarnya sama dengan siklus I, hanya saja materi yang disampaikan melanjutkan materi dari yang sebelumnya. Materi yang disampaikan pada siklus ini adalah Mencatat Jurnal Penyesuaian.

c. Pengamatan

Pengamatan dilakukan selama proses pembelajaran sama seperti pada siklus I.

d. Refleksi

Tahap refleksi dimaksudkan untuk mengkaji secara menyeluruh tindakan yang telah dilakukan berdasarkan data yang telah terkumpul baik dari siklus I maupun siklus II. Refleksi pada siklus II dilakukan setelah pembelajaran dilakukan. Refleksi siklus II digunakan untuk mengetahui apakah skor rata-rata Aktivitas dan Hasil Belajar Jurnal Penyesuaian dari siklus I ke siklus II sudah mengalami peningkatan dan mencapai kriteria minimal. Skor diketahui melalui analisis data berdasarkan hasil observasi dan tes. Penelitian tindakan ini dihentikan pada siklus II karena skor rata-rata aktivitas dan hasil belajar sudah mencapai kriteria minimal. 


\section{Teknik Pengumpulan Data}

Observasi partisipatif adalah teknik pengumpulan data yang dilakukan dengan cara mengamati dan mengikuti proses penelitian secara langsung dengan sumber data penelitian. Observasi partisipatif dalam penelitian ini dilakukan dengan mengikuti pembelajaran. Observasi yang dilakukan bertujuan untuk mengumpulkan data aktivitas belajar siswa pada saat pelaksanaan pembelajaran dengan Metode Pembelajaran Kooperatif Course Review Horay berlangsung. Aktivitas belajar siswa dinilai sesuai dengan pedoman observasi. Hasil penilaian untuk setiap siswa dijumlahkan lalu dipersentasekan untuk mengetahui skor aktivitas belajar siswa. Hasil penilaian pada siklus I dibandingkan dengan hasil penilaian siklus II.

Teknik lain yang digunakan untuk pengambilan data adalah tes. Sebagai alat pengukuran dalam evaluasi, tes memberikan data kuantitatif dalam bentuk nilai (angka). Penulis menggunakan pre test dan post test untuk mengetahui peningkatan hasil belajar. Kisi-kisi soal disesuaikan dengan indikator yang telah ditentukan dalam silabus.

Catatan lapangan digunakan dalam penelitian ini untuk mendeskripsikan situasi dan kondisi saat pembelajaran di kelas berlangsung. Catatan lapangan ini digunakan untuk mengumpulkan data tentang situasi dan kondisi saat proses pelaksanaan tindakan kelas.

Dalam penelitian ini, dokumentasi adalah teknik pengumpulan data menggunakan dokumen tertulis berupa administrasi guru yaitu silabus dan jadwal mengajar, serta daftar nilai yang digunakan sebagai dasar pembentukan kelompok dan tolok ukur awal hasil belajar siswa dalam pembelajaran akuntansi di kelas $\mathrm{X}$ Akuntansi SMK Muhammadiyah 2 Moyudan.

\section{Instrumen Penelitian}

\section{Lembar Observasi}

Lembar observasi digunakan untuk menilai aktivitas belajar siswa. Menurut Wina Sanjaya (2011: 92-93) instrumen observasi pada PTK merupakan pedoman bagi observer untuk mengamati hal-hal yang akan diamati. Penelitian ini menggunakan lembar observasi berbentuk rating scale, yaitu merupakan lembar observasi berisi pedoman yang digunakan dalam observasi termasuk di dalamnya terdapat daftar semua aspek yang akan diobservasi sehingga observer cukup memberikan tanda ada atau tidaknya aspek yang diobservasi.

Lembar observasi dalam penelitian ini menggunakan rating scale berbentuk numerical (numerical rating scale) dengan skor tertinggi untuk tiap butir 2 dan skor 
terendah 0 yang pada alternatif penilaiannya ditentukan dengan nomor sesuai kategori.

2. Pedoman Observasi

Untuk mendapatkan data yang diinginkan, penulis membatasi penyusunan Pedoman Observasi hanya terkait dengan aktivitas belajar siswa yang dapat diamati pada saat pembelajaran berlangsung.

3. Tes

Tes hasil belajar sebelum diaplikasikan dalam tahapan tiap siklus dibuat kisi-kisi soal terlebih dahulu disesuaikan dengan silabus berkaitan dengan aspek-aspek yang akan dinilai dalam pokok bahasan yang bersangkutan. Tes dibuat untuk mengetahui tingkat keberhasilan siswa menguasai materi jurnal penyesuaian yang diajarkan menggunakan metode Course Review Horay. Pemberian nilai kognitif menggunakan rentang nilai dari 1-100.

4. Catatan Lapangan

Catatan lapangan berupa formulir yang digunakan sebagai berita acara pelaksanaan pembelajaran dengan Metode Pembelajaran Kooperatif Course Review Horay. Catatan ini juga digunakan untuk merekam informasi mengenai hasil pengamatan atas aktivitas belajar siswa setelah implementasi Metode Pembelajaran Kooperatif Course Review
Horay dilaksanakan sehingga membantu dalam proses refleksi.

\section{Teknik Analisis Data}

Teknik analisis yang digunakan dalam penelitian ini adalah teknik analisis data deskriptif kuantitatif dengan persentase. Rumus yang digunakan untuk menghitung skor aktivitas pada setiap aspek yang diamati adalah: skor aktivitas belajar siswa

skor maksimum

Hasil belajar diperoleh dari tes. Nilai hasil belajar kognitif dihitung dengan menggunakan rumus sebagai berikut:

Siklus I Skor $=\mathrm{B} \times 10$

Siklus II Skor $=\frac{(\mathrm{B} \times 2)+(\mathrm{B} \times 4)}{3} \times 10$

Keterangan:

$\mathrm{B}=$ Jumlah butir soal yang benar dengan bobot nilai setiap soal 1 .

Rata-rata hasil belajar siswa dihitung dengan menggunakan rumus:

$$
\overline{\mathrm{X}}=\frac{\sum \mathrm{X}}{\mathrm{N}}
$$

Keterangan:

$$
\begin{aligned}
& \overline{\mathrm{X}}=\text { nilai rata-rata } \\
& \sum \mathrm{X}=\text { Jumlah nilai seluruh siswa } \\
& \mathrm{N}=\text { Banyaknya siswa }
\end{aligned}
$$

\section{Kriteria Keberhasilan Tindakan}

1. Peningkatan Aktivitas Belajar Siswa 
Kategori aktivitas belajar siswa ditinjau dari masing-masing aspek yang dirancang oleh penulis dengan menjumlah skor perolehan siswa dibagi dengan jumlah skor maksimum dikali $100 \%$. Indikator keberhasilan apabila rata-rata skor aktivitas belajar siswa secara klasikal mencapai minimal $75 \%$.

2. Peningkatan Hasil Belajar Siswa

Indikator keberhasilan tindakan ini adalah apabila minimal $75 \%$ dari jumlah siswa mendapat nilai hasil belajar ranah kognitif $\geq 75$ (KKM).

\section{HASIL DAN PEMBAHASAN}

Hasil penelitian diperoleh baik dari siklus I maupun siklus II. Hasil penelitian siklus I berdasarkan observasi diketahui bahwa indikator keberhasilan tindakan belum tercapai sebab skor untuk seluruh indikator belum mencapai kriteria minimal. Skor rata-rata aktivitas belajar jurnal penyesuaian siswa secara klasikal juga belum memenuhi sebab hanya mencapai 46,62\%. Pada siklus II indikator keberhasilan tindakan sudah tercapai walaupun masih terdapat dua indikator yang belum mencapai $75 \%$ tetapi skor rata-rata aktivitas belajar jurnal penyesuaian siswa secara klasikal sudah melebihi kriteria minimal yang ditetapkan yaitu didapatkan skor sebesar 79,88\%.
Berikut disajikan data aktivitas belajar jurnal penyesuaian pada siswa kelas $\mathrm{X}$ Akuntansi SMK Muhammadiyah 2 Moyudan Tahun Ajaran 2013/2014.

Tabel 1. Perbandingan Skor Aktivitas Belajar Jurnal Penyesuaian Siswa Siklus I dan Siklus II

\begin{tabular}{|c|c|c|c|c|}
\hline \multirow{2}{*}{ Indikator } & \multicolumn{2}{|c|}{ Skor (\%) } & \multicolumn{2}{|c|}{$\begin{array}{c}\text { Peningkat-an } \\
(\%)\end{array}$} \\
\hline & $\begin{array}{l}\text { Siklus } \\
\text { I }\end{array}$ & $\begin{array}{c}\text { Siklus } \\
\text { II }\end{array}$ & $\begin{array}{l}\text { Ab- } \\
\text { solut }\end{array}$ & $\begin{array}{l}\text { Re- } \\
\text { latif }\end{array}$ \\
\hline $\begin{array}{l}\text { Kegiatan- } \\
\text { kegiatan } \\
\text { visual }\end{array}$ & 36,84 & 85,71 & 48,87 & 132,65 \\
\hline $\begin{array}{l}\text { Kegiatan- } \\
\text { kegiatan } \\
\text { lisan }\end{array}$ & 34,21 & 74,60 & 40,39 & 118,06 \\
\hline $\begin{array}{l}\text { Kegiatan- } \\
\text { kegiatan } \\
\text { mende- } \\
\text { ngarkan }\end{array}$ & 57,89 & 85,71 & 27,82 & 48,06 \\
\hline $\begin{array}{l}\text { Kegiatan- } \\
\text { kegiatan } \\
\text { menulis }\end{array}$ & 39,47 & 60,71 & 21,24 & 53,81 \\
\hline $\begin{array}{l}\text { Kegiatan- } \\
\text { kegiatan } \\
\text { mental }\end{array}$ & 44,74 & 75,00 & 30,26 & 67,64 \\
\hline $\begin{array}{l}\text { Kegiatan- } \\
\text { kegiatan } \\
\text { metric }\end{array}$ & 72,37 & 98,81 & 26,44 & 36,53 \\
\hline $\begin{array}{l}\text { Kegiatan- } \\
\text { kegiatan } \\
\text { emosiona } \\
1\end{array}$ & 40,79 & 78,57 & 37,78 & 92,62 \\
\hline $\begin{array}{l}\text { Skor rata- } \\
\text { rata }\end{array}$ & 46,62 & 79,88 & 33,26 & 77,59 \\
\hline
\end{tabular}


Berdasarkan data yang dicantumkan di atas dapat dilihat bahwa terdapat peningkatan skor aktivitas belajar jurnal penyesuaian siswa menggunakan Metode Pembelajaran Course Review Horay pada siklus I dan siklus II. Pelaksanaan pembelajaran dengan Metode Pembelajaran Course Review Horay pada siklus I dan II terlihat aktivitas belajar jurnal penyesuaian siswa meningkat.

Selain aktivitas belajar, hasil belajar siswa juga diamati melalui pre test dan post test menggunakan soal yang telah dipersiapkan sebelumnya sesuai dengan materi yang diajarkan yaitu Jurnal Penyesuaian. Berikut disajikan data hasil belajar jurnal penyesuaian pada siswa kelas X Akuntansi SMK Muhammadiyah 2 Moyudan Tahun Ajaran 2013/2014.

Tabel 2. Perbandingan Ketuntasan Hasil Belajar Jurnal Penyesuaian Siswa Siklus I dan Siklus II

\begin{tabular}{cccc}
\hline \multicolumn{2}{c}{$\begin{array}{c}\text { Jumlah Siswa } \\
\text { Tuntas }(\%)\end{array}$} & \multicolumn{2}{c}{ Peningkatan (\%) } \\
Siklus I & Siklus II & Absolut & Relatif \\
\hline 10,53 & 76,19 & 65,66 & 623,55 \\
\hline
\end{tabular}

Berdasarkan data yang dicantumkan di atas dapat dilihat bahwa terdapat peningkatan hasil belajar jurnal penyesuaian siswa yang cukup besar menggunakan Metode Pembelajaran
Course Review Horay dari siklus I ke siklus II.

\section{SIMPULAN DAN SARAN}

\section{Simpulan}

Berdasarkan hasil penelitian, dapat diambil kesimpulan bahwa penerapan Metode Pembelajaran Course Review Horay dapat meningkatkan aktivitas dan hasil belajar jurnal penyesuaian pada siswa kelas X Akuntansi SMK Muhammadiyah 2 Moyudan Tahun Ajaran 2013/2014. Peningkatan ini terlihat dari kenaikan persentase Aktivitas dan Hasil Belajar Siswa dalam pembelajaran Akuntansi di kelas dengan materi Jurnal Penyesuaian.

Peningkatan aktivitas belajar tersebut dapat dilihat dari masing-masing indikator dari siklus I dan siklus II yaitu kegiatan-kegiatan visual $36,84 \%$ menjadi $85,71 \%$, kegiatan-kegiatan lisan 34,21\% menjadi 74,60\%, kegiatan-kegiatan mendengarkan $57,89 \%$ menjadi $85,71 \%$, kegiatan-kegiatan menulis $39,47 \%$ menjadi $60,71 \%$, kegiatan-kegiatan mental $44,74 \%$ menjadi $75,00 \%$, kegiatan-kegiatan metrik $72,37 \%$ menjadi $98,81 \%$, dan kegiatankegiatan emosional $40,79 \%$ menjadi $78,57 \%$. Skor rata-rata aktivitas belajar jurnal penyesuaian siswa juga meningkat dari $46,62 \%$ menjadi $79,88 \%$. Sedangkan peningkatan hasil belajar jurnal penyesuaian siswa dapat dilihat dari meningkatnya jumlah siswa yang 
memperoleh nilai post test minimal sama dengan kriteria ketuntasan minimal (KKM) yaitu 75 dan minimal $75 \%$ siswa secara klasikal dapat mencapai KKM. Pada siklus I hanya sebanyak 2 dari 19 siswa atau sebesar $9,52 \%$ yang berhasil mencapai nilai tuntas, dengan rata-rata nilai kelas sebesar 68,42. Pada siklus II jumlah siswa yang mencapai nilai tuntas naik menjadi 16 dari 21 siswa atau sebesar $76,19 \%$ dengan rata-rata nilai kelas 85,74 .

\section{Saran}

Beberapa saran yang dapat diberikan dari penelitian ini adalah sebagai berikut:

\section{Bagi Guru}

a. Sebaiknya

guru

perlu mempersiapkan dengan matang pengarahan dan bimbingannya kepada siswa dalam proses pembelajaran sehingga penguasaan dan pengelolaan kelas dapat dilakukan dengan optimal.

b. Sebaiknya guru memberikan kesempatan kepada siswa untuk menemukan dan memecahkan masalah sendiri, sehingga siswa terbiasa aktif berpikir.

c. Sebaiknya guru dapat terus mengimplementasikan metode pembelajaran yang bervariasi dan menarik sehingga tidak menimbulkan kebosanan bagi siswa. Metode Pembelajaran Course Review Horay dapat menjadi pilihan bagi guru untuk meningkatkan aktivitas dan hasil belajar siswa pada mata pelajaran akuntansi.

d. Penelitian ini diharapkan membawa dampak positif kepada guru agar tidak hanya menggunakan metode pembelajaran kooperatif pada saat penelitian saja, tetapi juga pada saat pelaksanaan pembelajaran seharihari.

2. Bagi Penulis Selanjutnya

a. Sebaiknya penelitian yang akan datang lebih teliti dalam observasi data sehingga diperoleh data yang benar-benar mewakili kondisi siswa selama proses pembelajaran berlangsung. Apabila jumlah siswa banyak dan tidak sebanding dengan jumlah observer yang sedikit, dibutuhkan alat yang mendukung seperti kamera perekam video atau bahkan CCTV agar hasil penelitian dapat benar-benar menggambarkan kondisi siswa.

b. Bagi penulis yang akan melakukan penelitian tindakan kelas hendaknya mempersiapkan segala sesuatunya dengan matang terutama komunikasi dengan guru kolaborator yang bersangkutan karena hal tersebut 
sangat membantu dalam proses pelaksanaan penelitan.

\section{DAFTAR PUSTAKA}

Arif Rohman. (2009). Memahami Pendidikan \& Ilmu Pendidikan. Yogyakarta: Laksbang Mediatama.

Asep Jihad \& Abdul Haris. (2008). Evaluasi Pembelajaran. Jakarta: Multi Press.

Dessy Anggraeni. (2011). "Peningkatan Kualitas Pembelajaran IPS Melalui Model Pembelajaran Kooperatif Tipe Course Review Horay pada Siswa Kelas IV SD Negeri Sekaran 01 Semarang". Jurnal Kependidikan Dasar KREATIF (Volume 1 Nomor 2). Hlm 194-205.

Eko Sugandi \& Sri Rahayu. (2012). "Upaya Meningkatkan Prestasi Belajar Matematika pada Pokok Bahasan Sistem Persamaan dan Pertidaksamaan Kudrat Melalui Model Pembelajaran Kooperatif Tipe Course Review Horay pada Siswa
Kelas X Akuntansi 1 SMK Negeri 1 Surabaya Tahun Ajaran 2011/2012". Makalah disampaikan dalam Seminar Nasional Pendidikan Matematika: Aplikasi Pendidikan Karakter dalam Pembelajaran Matematika. Surabaya: Universitas PGRI Adi Buana.

IKAPI. (2003). Undang-undang Republik Indonesia Nomor 20 Tahun 2003 tentang Sistem Pendidikan Nasional. Semarang: CV. Aneka Ilmu.

Nana Sudjana. (2005). Penilaian Hasil Proses Belajar Mengajar. Bandung: PT Remaja Rosdakarya.

Sulis Setiana. (2012). Peningkatan Hasil Belajar Matematika dengan Model Pembelajaran Kooperatif Tipe Course Review Horay (CRH) pada Siswa Kelas V SDN 2 Bulu Lor Jambon Ponorogo Tahun Pelajaran 2012/2013. Skripsi. Ponorogo: Fakultas Keguruan dan Ilmu Pendidikan Universitas Muhammadiyah Ponorogo.

Wina Sanjaya. (2011). Strategi Pembelajaran Berorientasi Standar Proses Pendidikan. Jakarta: Kencana. 